\title{
Cytochrome P450, peroxisome proliferation, and cytoplasmic fatty acid-binding protein content in liver, heart and kidney of the diabetic rat
}

Citation for published version (APA):

Engels, W., van Bilsen, M., Wolffenbuttel, B. H. R., van der Vusse, G. J., \& Glatz, J. F. (1999).

Cytochrome $\mathrm{P} 450$, peroxisome proliferation, and cytoplasmic fatty acid-binding protein content in liver, heart and kidney of the diabetic rat. Molecular and Cellular Biochemistry, 192(1-2), 53-61. https://doi.org/10.1023/A:1006855214237

Document status and date:

Published: 01/01/1999

DOI:

10.1023/A:1006855214237

Document Version:

Publisher's PDF, also known as Version of record

Document license:

Taverne

Please check the document version of this publication:

- A submitted manuscript is the version of the article upon submission and before peer-review. There can be important differences between the submitted version and the official published version of record.

People interested in the research are advised to contact the author for the final version of the publication, or visit the DOI to the publisher's website.

- The final author version and the galley proof are versions of the publication after peer review.

- The final published version features the final layout of the paper including the volume, issue and page numbers.

Link to publication

\footnotetext{
General rights rights.

- You may freely distribute the URL identifying the publication in the public portal. please follow below link for the End User Agreement:

www.umlib.nl/taverne-license

Take down policy

If you believe that this document breaches copyright please contact us at:

repository@maastrichtuniversity.nl

providing details and we will investigate your claim.
}

Copyright and moral rights for the publications made accessible in the public portal are retained by the authors and/or other copyright owners and it is a condition of accessing publications that users recognise and abide by the legal requirements associated with these

- Users may download and print one copy of any publication from the public portal for the purpose of private study or research.

- You may not further distribute the material or use it for any profit-making activity or commercial gain

If the publication is distributed under the terms of Article $25 \mathrm{fa}$ of the Dutch Copyright Act, indicated by the "Taverne" license above, 


\title{
Cytochrome $\mathbf{P 4 5 0}$, peroxisome proliferation, and cytoplasmic fatty acid-binding protein content in liver, heart and kidney of the diabetic rat
}

\author{
Wim Engels, ${ }^{1}$ Marc van Bilsen, ${ }^{2}$ Bruce H.R. Wolffenbuttel,,${ }^{1}$ Ger J. van \\ der Vusse ${ }^{2}$ and Jan F.C. Glatz ${ }^{2}$ \\ ${ }^{1}$ Department of Internal Medicine and ${ }^{2}$ Department of Physiology, Cardiovascular Research Institute Maastricht (CARIM), \\ Maastricht University, Maastricht, The Netherlands
}

\begin{abstract}
Diabetes mellitus generally results in an increased systemic fatty acid mobilization which can be associated with an increase in mitochondrial and peroxisomal $\beta$-oxidation of fatty acids in selected tissues. The latter is usually accompanied by a concomitant increase in the tissue content of cytoplasmic fatty acid-binding protein (FABP) which functions in the intracellular translocation of fatty acids. It was previously found that in liver clofibrate-induced proliferation of peroxisomes and increase in FABP expression each are dependent on the induction by cytochrome P4504A1 -mediated (CYP4A1) formation of dicarboxylic acids. We studied whether peroxisome proliferation and an increase of FABP contents in liver, heart and kidney of streptozotocininduced diabetic rats are also accompanied by an increase of CYP4A1 activity, as this would indicate a possible regulatory role for dicarboxylic acids in peroxisome proliferation and FABP induction in diabetic organs other than liver. In livers of the diabetic rat, a concomitant increase was observed of the activities of CYP4A1 and the peroxisomal key enzyme fatty acyl-CoA oxidase (FACO) and of the FABP content. In the diabetic heart FACO activity and FABP content also increased, but there was no induction of CYP4A1 activity. Conversely, in diabetic kidney there was no increase in FACO activity nor FABP content in spite of a marked induction of CYP4A1 activity. It is concluded that streptozotocin-induced diabetes leads to increased peroxisome proliferation and increased levels of FABP in both liver and heart, which only in liver is accompanied by an induction of the cytochrome P450 system. Consequently, it is not likely that dicarboxylic acids are involved in the induction of peroxisome proliferation in the heart. (Mol Cell Biochem 192: 53-61, 1999)
\end{abstract}

Key words: diabetes mellitus, cytochrome $\mathrm{P} 450$ 4A, fatty acid-binding protein, peroxisome proliferation, streptozotocin, rat

Abbreviations: EC - ethoxycoumarin; FACO - fatty acyl CoA oxidase; FABP - fatty acid-binding protein; MES - $\beta$-morpholinoethanesulfonic acid; MOPS - 3-[N-Morpholino] propane sulfonic acid; PPAR - peroxisome proliferator-activated-receptor; PPRE - peroxisome proliferator reponse element

\section{Introduction}

Diabetes mellitus is well known to lead to profound changes in whole body fatty acid metabolism. In both insulindependent and non-insulin dependent diabetes mellitus, glucose uptake and/or metabolism by extra-hepatic tissues is decreased, causing an increased mobilization of fatty acids from adipose tissue and a shift towards increased utilization of fatty acids by liver, heart and skeletal muscles [1]. Uncontrolled diabetes mellitus leads to a fatty acid overload, which is accompanied by an increased capacity for oxidation of fatty acids by the mitochondrial, 
peroxisomal and microsomal pathways of liver and heart [2].

Under normal circumstances, the peroxisomal $\beta$-oxidation is only a minor pathway for fatty acid oxidation relative to the mitochondrial counterpart, although it appears to be of particular importance for the $\beta$-oxidation of very-long-chain fatty acids which are poor substrates in the mitochondrial oxidative pathway [3-5]. Diets containing (very) long-chain fatty acids not only induce in liver the enzymes of both peroxisomal and microsomal oxidation [6], but also the cytoplasmic liver-type fatty acid-binding protein (L-FABP) [7]. This protein exhibits marked affinity for long-chain fatty acids and is considered to play a significant role in the cellular uptake and intracellular targeting of fatty acids [8]. Therefore, in the transport and metabolism of long-chain fatty acids during fatty acid overload, the expression of FABP and the activity of peroxisomal enzymes, respectively, each play a crucial role. However the precise mechanisms underlying the regulation of FABP expression and peroxisome proliferation are still unknown.

In liver the proliferation of peroxisomes and the induction of FABP have been demonstrated to be invariably dependent on the cytochrome P450 system localized at the endoplasmic reticulum $[5,9]$. This was seen both under conditions of fatty acid overload and after administration of so-called peroxisome proliferators, such as clofibrate [9]. The mechanism has been proposed to be an adaptive response to altered intracellular fatty acid fluxes, mediated by dicarboxylic fatty acids formed via the cytochrome P4504A1 (CYP4A1) $\omega$-oxidation pathway [9]. In this pathway long-chain fatty acids are first hydroxylated on the omega position, then oxidized via an intermediary aldehyde to a dicarboxylic acid [10] and finally converted into their CoA derivative $[6,10]$. Recently, a soluble receptor termed peroxisome-proliferator-activated receptor (PPAR) belonging to the nuclear hormone receptor superfamily has been isolated [11]. These receptors are ligand-activated transcription factors and can bind to specific DNA sequences, i.e. the so-called peroxisome proliferator response elements (PPRE). The detection by Northern blotting of PPAR-specific mRNA in liver, heart, kidney, gut and brown adipose tissue of the rat, suggests its involvement in regulating aspects of peroxisomal function and fatty acid homeostasis [12]. However, none of the peroxisomal proliferators tested thus far has been shown to bind to PPAR while the endogenous ligands of this receptor remain unknown [13].

Under starved and diabetic conditions, co-induction in liver of peroxisomal fatty acid $\beta$-oxidation and microsomal fatty acid $\omega$-oxidation has also been established $[14,15]$. Conversely, conditions of hyperinsulinemia inhibit hepatic peroxisomal $\beta$-oxidation in rats [16]. Therefore, it is reasonable to hypothesize that in diabetes mellitus peroxisomal fatty acid $\beta$-oxidation and microsomal $\omega$-oxidation in rat liver are cooperatively regulated by PPAR in order to achieve an optimal utilization of fatty acids. With respect to kidney and heart, no data are available. The notion that dicarboxylic acids might play a role in these inductive processes in diabetes is substantiated by the observation that in diabetic rats the urinary excretion of dicarboxylic acids is enhanced [10]. However, Gustafsson et al. [17] demonstrated in liver that the cytochrome P450 system as well as dicarboxylic acids do not play a role in peroxisome proliferation. The assembled findings indicate that the precise mechanism of the induction of peroxisome proliferation and of FABP in liver, heart and kidney is not yet fully understood.

The aim of the present study was to determine whether in experimental diabetes, as induced by streptozotocin injection, CYP4A1 activity is implicated in peroxisome proliferation, in the induction of FABP, and/or in the induction of CYP4A1 itself, as was postulated by Kaikaus et al. [9, 18, 19] for clofibrate administration and high-fat feeding, and, if so, whether possible organ-specific mechanisms are involved. For this, we measured in rat liver, heart, and kidney not only CYP4A1 activity, but also the activities of CYP1A1 as a generally inducible cytochrome P450-related enzyme and of CY1P2El, a cytochrome P450 subspecies which is induced particularly under diabetic conditions [20]. Peroxisome proliferation was assessed by measuring the activity of fatty acyl-CoA oxidase (FACO). FABP was determined as L(iver) and H(eart)-type FABP by ELISA's type-specific antibodies.

Our data presented in this study indicate marked differences in the response of these organs towards conditions of streptozotocin-induced hyperglycemia with respect to peroxisome proliferation, FABP levels and CYP4A1 induction, thereby questioning the general role of cytochrome P450 related metabolites, such as dicarboxylic acids, in the process of a coordinated induction.

\section{Materials and methods}

\section{Chemicals}

Streptozotocin, clofibrate, 7-ethoxycoumarin, bovine serum albumin (fraction V), lauric acid, 11-hydroxy and 12-hydroxy lauric acid, 110-hydroxy caproic acid, arachidonic acid, MES ( $\beta$-morpholino-ethanesulfonic acid), MOPS (3-[NMorpholino]propane sulfonic acid) and Tris-HCl were obtained from Sigma Chemicals (St. Louis, MO, USA). Acetonitrile, diethyl ether, and tetrahydrofuran were purchased from Rathburn (Walkerburn, UK). Panacyl bromide [p-(9anthroyl)phenacyl bromide] was from Molecular Probes Inc. (Eugene, OR, USA). NADH, NADPH, NADP ${ }^{+}$, glucose-6phosphate and glucose-6-phosphate dehydrogenase were obtained from Boehringer Mannheim (Mannheim, Germany). All other chemicals were at least reagent grade (Merck, Darmstadt, Germany). 


\section{Animals}

Experiments were performed with adult male Wistar rats (Winkelmann, Borchen, FRG) (body wt 250-300 g). Animals were fed ad libitum (Diet SRIVI-A, Hope Farms, Woerden, The Netherlands), had free access to water, and were kept under an artificial dark-light cycle of $12 \mathrm{~h}$. The experiments were approved by the Institutional Animal Care and User Committee of Maastricht University.

\section{Treatment}

Insulin-dependent diabetes was evoked by a single intravenous injection of streptozotocin $(55 \mathrm{mg} / \mathrm{kg}$ body $\mathrm{wt})$ as described in detail by Glatz et al. [21]. The rats were sacrificed after 3 weeks.

In a subset of experiments $(n=8)$ clofibrate was used as peroxisome proliferator. Hereto, clofibrate was administered daily for 7 days via an oral cannula. A solution of $80 \mathrm{mg}$ of the drug per $\mathrm{ml}$ glycerol $(60 \%)$ was given so that each rat received $250 \mathrm{mg} / \mathrm{kg}$ per day of clofibrate.

\section{Blood glucose}

Blood glucose concentrations were measured with a glucose sensor electrode (Medisense Inc., Waltham, MA, USA) in whole blood obtained by orbital punction.

\section{Tissue homogenization and isolation of microsomes}

Liver, heart and kidney were dissected and treated as described by McCallum et al. [22]. Briefly, rats were heparinized by an intraperitoneal injection of 1000 UThromboliquine (Organon Technika, Oss, The Netherlands). After $10 \mathrm{~min}$, the animals were decapitated and liver, heart, and kidney were quickly removed and weighed. Immediately thereafter, the organs were freeze-clamped and stored at $-80^{\circ} \mathrm{C}$ until further analysis. Tissue was pulverized in an aluminum mortar cooled with liquid nitrogen and subsequently homogenized in 0.15 $\mathrm{M} \mathrm{KCl}$ and $50 \mathrm{mM}$ potassium phosphate, $\mathrm{pH} 7.4$, at $0-4^{\circ} \mathrm{C}$ using a Potter-Elvehjem glass-Teflon homogenizer. Thereafter, microsomes were prepared by differential centrifugation as described by Rutten et al. [23]. The pellet was resuspended carefully with a $5 \mathrm{ml}$ glass-Teflon homogenizer in ice-cold $0.15 \mathrm{M} \mathrm{KCl}$ in a volume equal to the original organ weight.

For the determination of FABP freeze-clamped tissue was homogenized as a $10 \%(\mathrm{w} / \mathrm{v})$ solution in $50 \mathrm{mM}$ Tris- $\mathrm{HCl}$, $\mathrm{pH} 7.4$, with an Ultraturrax (50 Watt) during three periods of $5 \mathrm{sec}$ with $10 \mathrm{sec}$ intervals at $0^{\circ} \mathrm{C}$.

\section{Fatty acyl-CoA oxidase (FACO)}

Fatty acyl-CoA oxidase activity was measured using palmitoyl-CoA as the substrate, as described by Vannecq [24]. Briefly, the homogenates were freshly prepared by homogenizing the freeze-clamped organ tissue in Mannaerts buffer (10 mM tetrasodium pyrophosphate ( $\mathrm{pH} 9.0), 10 \mu \mathrm{M}$ $\mathrm{FAD}^{+}$and $1 \mathrm{mM}$ EDTA) [25]. Then, $10 \mu \mathrm{l}$ of the homogenate (containing 50-100 $\mu \mathrm{g}$ total protein) was added to $2 \mathrm{ml}$ of a reaction mixture containing $100 \mathrm{mM}$ HEPES (pH 7.6), $1 \mathrm{mM}$ homovanillic acid, $1 \mu \mathrm{g}$ horse radish peroxidase, $5 \mu \mathrm{M} \mathrm{FAD}^{+}$, $1 \mathrm{mM} \mathrm{NaN}_{3}, 240 \mu \mathrm{g}$ bovine serum albumin (fatty acid free), and $0.06 \%$ Triton $\mathrm{X}-100$. The reaction temperature was $37^{\circ} \mathrm{C}$, and the cuvet was equipped with a stirring bar at the bottom. The reaction was started by addition of $100 \mu$ l of a palmitoylCoA solution ( $1 \mathrm{mM}$ in $20 \mathrm{mM}$ MES buffer). The increase in fluorescence was measured during 15 min on a Shimadzu RF-5001PC fluorescence spectrophotometer (settings: excitation wavelength $327 \mathrm{~nm}$, and emission wavelength 428 $\mathrm{nm})$.

\section{FABP assay}

Tissue contents of L(iver-type)-FABP and H(eart-type)FABP each were measured by specific affinity-enzymelinked immuno-sorbent assays of the antigen capture type (sandwich-ELISAs), using purified IgG antibodies directed against purified rat L- or H-FABP and the streptavidin-biotin detection system as described by Vork et al. [26] and Van Nieuwenhoven et al. [27]. The cross-reactivities of H-FABP in the assay for L-FABP, and conversely, were found to be less than $0.002 \%$.

\section{Spectroscopic determination of cytochrome P450}

Determinations of cytochrome P450 content of the microsomal preparations was based on the reduced carbon monoxide difference spectrum, using sodium dithionite as the reducing agent, according to Onnura and Sato [28], as described by Stegeman et al. [29]. Microsomal suspensions containing about $1 \mathrm{mg}$ of protein per $\mathrm{ml}$ were used. The cytochrome $\mathrm{P}-450$ content was calculated from the absorbance difference between 450 and $490 \mathrm{~nm}$, using a molar extinction coefficient of $91 \mathrm{mM}^{-1} \mathrm{~cm}^{-1}$ [28].

\section{CYP4A1 activity}

This activity was measured as the omega-hydroxylation of lauric acid. Hereto we developed a new specific HPLC method, using panacyl bromide as the fluorescent derivative. 
Reaction mixtures containing microsomes (1-2 mg of protein), $100 \mathrm{nM}$ lauric acid (added as a stock solution of $10 \mathrm{mM}$ in ethanol), $0.1 \mathrm{ml}$ of a NADPH regenerating system (10 mg NADH, 7.9 mg NADP ${ }^{+}, 6.8 \mathrm{mg}$ glucose-6-phosphate, $14 \mu$ l glucose-6-phosphate dehydrogenase, and 6.8 $\mathrm{mg} \mathrm{MgCl} 2$ in $1 \mathrm{ml}$ of $100 \mathrm{mM}$ potassium phosphate buffer, $\mathrm{pH}$ 7.4) in a final reaction volume of $1 \mathrm{ml}$ of $100 \mathrm{mM}$ potassium phosphate buffer, $\mathrm{pH} 7.4$, were incubated at $37^{\circ} \mathrm{C}$ for $10 \mathrm{~min}$ in an orbital shaking water bath (200 rpm). The reaction was stopped by the addition of $50 \mu$ of acetic acid. The formation of the hydroxy derivatives of lauric acid was linear with time until at least $60 \mathrm{~min}$. After addition of the internal standard 10-hydroxy caproic acid, the samples were extracted twice with $3 \mathrm{ml}$ of diethyl ether. The organic phases were collected and dried under a stream of nitrogen at $40^{\circ} \mathrm{C}$. The residue was dissolved in diethyl ether-acetic acid $(100: 0.5, \mathrm{v} / \mathrm{v})$ and consecutively fractionated by silica gel chromatography, purified by reverse-phase chromatography, and derivatized with panacyl bromide as described earlier [30]. The panacyl esters were solubilized in $100 \mu 1$ of acetonitrile and were analyzed by $\mathrm{C}_{18}$ reversed-phase HPLC with fluorimetric detection. The HPLC system consisted of a Lichrocart Supersphere 100-RP-18 column $(250 \times 4 \mathrm{~mm}$ ID, $4 \mu \mathrm{m}$ particles with a precolumn guard cartridge) (Merck Darmstadt, Germany), a Spectroflow 400 pump (Kratos Analytical, Ramsey, NJ, USA) with a Rheodyne 7125 loop injector (Cotati, CA, USA), and a Jasco fluorescence detector (Jasco Corporation, Tokyo, Japan). The settings were: Excitation wavelength $360 \mathrm{~nm}$ and emission wavelength 480 $\mathrm{nm}$. The mobile phase was acetonitrile-water $(80: 20, \mathrm{v} / \mathrm{v})$. The injection volume was $20 \mu \mathrm{l}$ and the flow rate $0.5 \mathrm{ml} / \mathrm{min}$.

\section{CYP1A1 activity}

This activity was measured as the deethylation of ethoxycoumarin (EC) using a $1.0 \mathrm{ml}$ of a reaction mixture containing $2 \mu \mathrm{M} \mathrm{EC}, 0.1 \mathrm{mM}$ Tris ( $\mathrm{pH} 8.0$ ), $0.1 \mathrm{ml} \mathrm{M} \mathrm{NaCl}$, and $20 \mu \mathrm{l}$ microsomes (3-8 $\mathrm{mg}$ of microsomal protein per $\mathrm{ml}$ ). The reaction was started at $37^{\circ} \mathrm{C}$ by the addition of NADPH (final concentration $0.5 \mathrm{mM}$ ), and the appearance of coumarin was monitored with a fluorescence spectrophotometer (Shimadzu RF-5001PC). The fluorimeter settings were: Excitation wavelength $530 \mathrm{~nm}$ and emission wavelength $585 \mathrm{~nm}$.

\section{CYP2E activity}

This activity was measured as the conversion of p-nitrophenol into 4-nitrocatechol according to Reinke [31] using a $2 \mathrm{ml}$ incubation mixture containing $1.58 \mathrm{ml}$ incubation buffer (50 $\mathrm{mM}$ Tris, $\mathrm{pH} 7.4,5 \mathrm{mM} \mathrm{MgSO}_{4}$ ), $0.20 \mathrm{ml}$ of a NADPH regenerating system (see above) and $0.20 \mathrm{ml}$ of microsome suspension. The reaction was started by addition of $20 \mu \mathrm{l}$ of a p-nitrophenol solution $(20 \mathrm{mM})$ and the mixture was incubated at $37^{\circ} \mathrm{C}$ for $30 \mathrm{~min}$. The reaction was stopped by addition of $0.5 \mathrm{ml} 0.6 \mathrm{M} \mathrm{HClO}_{4}$. After centrifugation at 2000 $\times \mathrm{g}$ for $10 \mathrm{~min}, 150 \mu \mathrm{l} 10 \mathrm{M} \mathrm{KOH}$ was added to $1.5 \mathrm{ml}$ supernatant. The tubes were placed in ice for $30 \mathrm{~min}$ and subsequently centrifuged at $2000 \times \mathrm{g}$ for $10 \mathrm{~min}$. The extinction of the supernatants was measured spectrophotometrically at $546 \mathrm{~nm}$. Hydroxylase activity was calculated based on the formation of 4-nitrocatechol, for which a molecular extinction coefficient of $10.28 \mathrm{mM}^{-1} \cdot \mathrm{cm}^{-1}$ was used.

\section{Protein determination}

Protein concentrations were determined by the Micro BCA (Bicinchoninic acid) assay (Pierce Chem Co., Rockford, IL, USA), using bovine serum albumin (fraction V, Sigma Chemicals) as the standard.

\section{Statistics}

Data are presented as mean values \pm S.D. Comparisons between groups were made using one-way analysis of variance followed by Tukey's method for multiple comparisons [32]. P values $\leq 0.05$ were considered to be statistically significant.

\section{Results}

\section{General}

The insulin-dependent diabetic state of the streptozotocintreated adult rats manifested as a high plasma glucose concentration $(20-25 \mathrm{mM})$ and a considerable loss $(-27 \%)$ of body weight (Table 1). An increase of organ weight was observed only for kidney $(+20 \%)$, probably due to hypertrophy [33]. In contrast, the absolute heart weight of the diabetic rats decreased significantly $(-21 \%)$ when compared to the controls. No significant change in liver weight was observed.

\section{Peroxisome proliferation}

Generally, diabetes mellitus is characterized by a condition of increased mobilization of fatty acids which might lead to an increase of peroxisomal activity. Therefore, we measured peroxisomal activity based on the peroxisomal enzyme fatty acyl-CoA-oxidase (FACO) (Fig. 1). A significant increase of 
Table 1. Body weight, blood plasma glucose concentration and organ weights in control and streptozotocin-induced diabetic rats

\begin{tabular}{llllll}
\hline Condition & $\begin{array}{l}\text { Body weight } \\
(\mathrm{g})\end{array}$ & $\begin{array}{l}\text { Glucose } \\
(\mathrm{mM})\end{array}$ & $\begin{array}{l}\text { Liver } \\
(\mathrm{g})\end{array}$ & $\begin{array}{l}\text { Heart } \\
(\mathrm{g})\end{array}$ & $\begin{array}{l}\text { Kidney } \\
(\mathrm{g})\end{array}$ \\
\hline Control & $329 \pm 25$ & $7.0 \pm 0.7$ & $13.3 \pm 1.5$ & $1.03 \pm 0.11$ & $\begin{array}{l}1.22 \pm 0.10 \\
(0.37 \%)\end{array}$ \\
& & & $(4 \%)$ & $(0.31 \%)$ & $1.47 \pm 0.17^{*}$ \\
Diabetes & $240 \pm 39^{*}$ & $22.5 \pm 2.7^{*}$ & $11.9 \pm 1.7$ & $0.81 \pm 1.7$ & $(0.61 \%)$ \\
& & & $(5 \%)$ & $(0.33 \%)$ & \\
\hline
\end{tabular}

Values are means \pm S.D. $(n=6)$. Values in parentheses refer to mean organ weight expressed as percentage of total body weight. Statistical significance was determined by Tukey's test. *p $<0.05$.

FACO was observed in both liver $(+62 \%)$ and heart $(+265 \%)$. However, in kidney the FACO activity of the diabetic group did not differ from the control.

FABP

The diabetic animals showed an increase by $40-50 \%$ in the content of both L-FABP in liver and H-FABP in the heart (Table 2). In kidney from the control rats the amounts of Land H-FABP were low when compared to those in liver and heart (Table 2). The 5-10 fold higher kidney content of $\mathrm{H}-\mathrm{FABP}$ compared to L-FABP in control animals agrees with an earlier report [34]. A small but significant decrease of the L-FABP content was observed in kidney the diabetic animals,

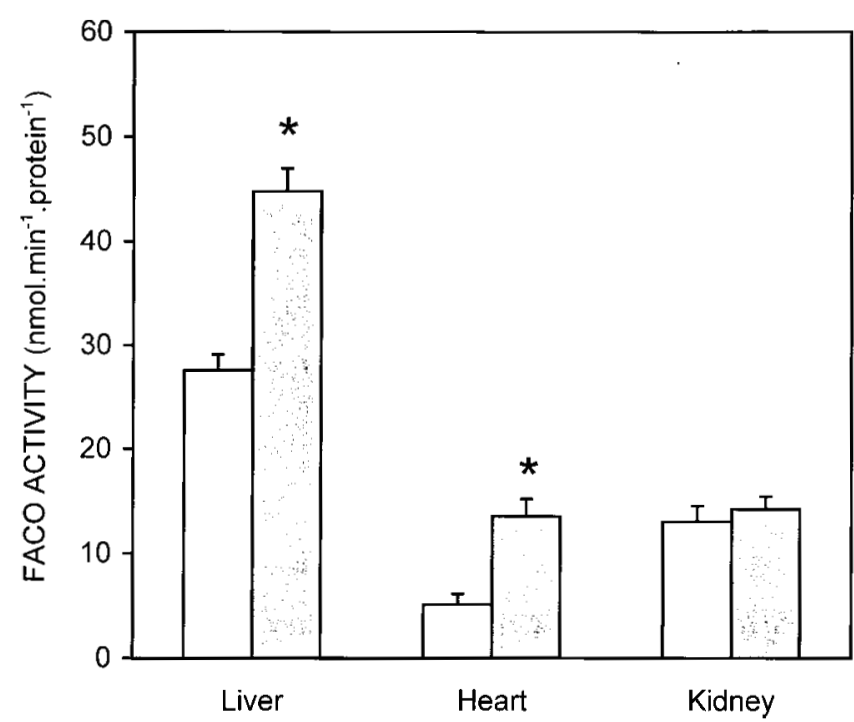

Fig. 1. Activities of the peroxisomal enzyme fatty acyl-CoA oxidase (FACO) in liver, heart and kidney of control and streptozotocin-induced diabetic rats. Activities were measured in tissue whole homogenates and are represented as means \pm S.D. $(n=6)$. Statistical significance was determined by Tukey's test. * $\mathrm{p}<0.05$, compared with the control group. Open bars, control animals; dark bars, streptozotocin-induced diabetic animals. whereas the contents of H-FABP did not differ significantly between diabetic and control rats.

\section{Cytochrome P450}

To explore whether peroxisome proliferation is a cytochrome $\mathrm{P} 450$-dependent process, in which the formation of dicarboxylic acids is crucial, we measured in addition to the total content of cytochrome P450 also the activity of CYP4A1 (based on $\omega$ - and $\omega$-1 hydroxylation of lauric acid). Moreover, to assess the specificity of the cytochrome P450 induction, the activity of CYP1A1 and CYP2E was measured (Table 3 ). In both liver and kidney a 2 to 3 -fold increase in the total content of cytochrome P450 was observed. In contrast, in heart cytochrome P450 or CYP4A1 activity (even after prolonged incubation times up to $1 \mathrm{~h}$ ) could not be demonstrated. CYP4A1 activities were increased in liver and kidney of diabetic animals, but not in the heart. Ethoxycoumarin deethylase (CYP1A1) and p-nitrophenol (CYP2E) hydroxylase could be demonstrated only in liver. In kidney and heart these activities were not detectable, neither in control, nor in streptozotocin-treated animals.

Since streptozotocin might be a weak inducer of the cytochrome $\mathrm{P} 450$ system in heart, in a separate set of animals $(\mathrm{n}=8)$ we used clofibrate, a compound commonly used to

Table 2. Content of liver-type(L-) and heart-type (H-) FABP in liver, heart and kidney of streptozotocin-induced diabetic and control rats

\begin{tabular}{|c|c|c|c|}
\hline Tissue & Condition & $\begin{array}{l}\text { L-FABP } \\
\left(\mu \mathrm{g} . \mathrm{mg} \text { protein }{ }^{-1}\right)\end{array}$ & $\begin{array}{l}\text { H-FABP } \\
\left(\mu \mathrm{g} . \mathrm{mg} \text { protein }{ }^{-1}\right)\end{array}$ \\
\hline \multirow[t]{2}{*}{ Liver } & Control & \pm 2.5 & $<0.0002$ \\
\hline & Diabetes & $12.4 \pm 2.2 *$ & $<0.0002$ \\
\hline \multirow[t]{2}{*}{ Heart } & Control & $0.005 \pm 0.012$ & $5.1 \pm 0.6$ \\
\hline & Diabetes & $0.002 \pm 0.012$ & $7.4 \pm 0.8^{*}$ \\
\hline \multirow[t]{2}{*}{ Kidney } & Control & $0.031 \pm 0.010$ & $0.12 \pm 0.02$ \\
\hline & Diabetes & $0.012 \pm 0.007 *$ & $0.14 \pm 0.05$ \\
\hline
\end{tabular}

FABP contents were measured in tissue whole homogenates and are expressed as means \pm S.D. $(n=6)$. Statistical significance was determined by Tukey's test. $* \mathrm{p}<0.05$ 
Table 3. Cytochrome P450 content and activities of $\omega$ - and $\omega$-1-hydroxylation, 7-ethoxycoumarine deethylase, and p-nitrophenol in microsomal preparation in liver, heart and kidney of streptozotocininduced diabetic rats.

\begin{tabular}{|c|c|c|c|c|c|c|}
\hline Tissue & Condition & Cytochrome P450 & $\begin{array}{l}\text { Omega } \\
\text { hydroxylation }^{\mathrm{b}} \\
\text { (CYP4A1) }\end{array}$ & $\begin{array}{l}\text { Omega } \\
\text { hydroxylation }^{\mathrm{b}} \\
\text { (CYP4A1) }\end{array}$ & $\begin{array}{l}\text { Ethoxycournarin } \\
\text { deethylase } \\
\text { (CYP1Al) }\end{array}$ & $\begin{array}{l}\text { p-Nitropheno } \\
\text { hydroxylase }^{c} \\
\text { (CYP2E) }\end{array}$ \\
\hline & diabetes & $1.69 \pm 0.37 *$ & $3.18 \pm 0.51$ & $1.41 \pm 0.10^{*}$ & $1.79 \pm 0.42 *$ & $1.82 \pm 0.12 *$ \\
\hline \multirow[t]{2}{*}{ Heart } & control & $<0.01$ & $<0.01$ & $<0.01$ & $<0.01$ & $<0.01$ \\
\hline & diabetes & $<0.01$ & $<0.01$ & $<0.01$ & $<0.01$ & $<0.01$ \\
\hline & diabetes & $0.37 \pm 0.12 *$ & $2.06 \pm 0.54 *$ & $0.65 \pm 0.25$ & $<0.01$ & $<0.01$ \\
\hline
\end{tabular}

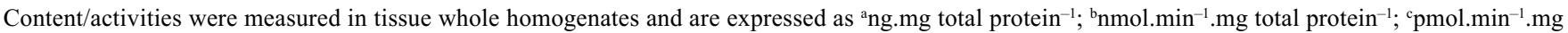
total protein ${ }^{-1}$, respectively. Values are means \pm S.D. $(n=6)$. Statistical significance was determined by Tukey's test. * $\mathrm{p}<0.05$.

induce peroxisome proliferation [18]. In liver a significant increase in cytochrome P450 content (3-fold) and in CYP4A1 activity (4-fold) occurred. In heart no increased activity could be demonstrated. Nevertheless, peroxisomal $\beta$ oxidation, as assessed by FACO activity, increased 14-fold in liver and 3-fold in heart (data not shown). Additional experiments with $\beta$-naphtoflavone and phenobarbital as potent inducers of cytochrome P4501A1 in heart [22, 35] neither resulted in detectable amounts of cytochrome $\mathrm{P} 450$, nor of CYP4A1 activity in the heart (data not shown). In contrast, in the present study these compounds gave in liver a considerable and comparable induction of omega hydroxylation $(+420 \%)$, ethoxycournarin deethylation $(+160 \%)$, aniline hydroxylation $(+300 \%)$ and $6 \beta$-testosterone hydroxylation $(+240 \%)$.

\section{Discussion}

In the present study we explored the effect of streptozotocininduced diabetes mellitus on peroxisome proliferation, cytochrome P450 activity and the content of cytoplasmic FABP in various tissues of the rat. In liver there was a co-induction of all three parameters, which finding extends the previous observations of Kaikaus et al. [18, 19] in clofibrate-treated rats, and suggests that also in the liver of diabetic animals the increase in peroxisome proliferation and L-FABP content is induced by dicarboxylic acids formed in the cytochrome $\mathrm{P} 450$ pathway. However, in the diabetic heart we found both an increased peroxisome proliferation and H-FABP content, but no detectable CYP4A1 activity, while in kidney an induction of CYP4A1 was seen in combination with a decreased L-FABP content, an unchanged H-FABP content and peroxisomal activity. These findings strongly suggest that peroxisome proliferation and H-FABP induction in the heart take place via a mechanism not involving CYP4A1 metabolites (such as dicarboxylic acids) and, conversely, that the enhanced CYP4A1 activity, as seen in kidney, does not necessarily lead to an induction of peroxisome proliferation and induction of either cytoplasmic L- or H-type FABP.

A potential role for dicarboxylic fatty acids, produced from long-chain monocarboxylic fatty acids via CY1P4A1, as mediators of the peroxisome proliferator response and possible ligands of PPAR, has been demonstrated in rat liver [18]. In contrast, Gustafson and coworkers demonstrated that the induction of peroxisome proliferation in rat liver by long-chain fatty acids was not dependent of cytochrome P450 and that dicarboxylic acids did not activate PPAR [17]. At present, no explanation can be given for these contradictory results. Additionally, it was shown by Göttlicher et al. [36, 37] that PPAR can be activated by long-chain fatty acids $p e r$ $s e$. These workers also demonstrated that $\beta$-oxidation of the inducing fatty acid is not required and that blocking of the $\beta$-oxidative pathway increases the potency of fatty acids or of an, as yet, unidentified metabolite for activating PPAR, most likely due to enhanced levels of unmetabolized longchain fatty acids [37]. The latter would be in agreement with the suggestion made by Isseman et al. [7] that a rapid metabolism of $\beta$-oxidizable fatty acids within the cell requires high concentrations of these fatty acids to activate PPAR. This notion is also supported by the observation of Kaikaus et al. [19] that oleic acid alone was unable to stimulate peroxisomal $\beta$-oxidation or the expression of FAI3P, but in the presence of an inhibitor of carnitine palmitoyl transferase 1, induced peroxisomal $\beta$-oxidation and the expression of FABP pretranslationally.

In general, streptozotocin-induced diabetes not only leads in liver to the induction of CYP4A1, but also of subspecies, such as CYP1A1, CYP2E [38, 39]. The most well-defined change in livers of diabetic rats with respect to cytochrome P450 is the induction of CYP2E1 and this elevation can be reversed by treatment with insulin [39]. Data from the study of Shimojo [39] indicate that during diabetes most probably the enhanced production of ketone bodies is primarily responsible for the induction of CYP1A1 and CYP2E, 
whereas fatty acid overload results in an increased expression of CYP4A1.

Although it is well documented that administration of peroxisome proliferators, such as clofibrate, results in a markedly increased content of L-FABP in rat liver [18], data on tissue FABP levels under diabetic conditions are limited. In this study a significant increase in L-FABP content could be demonstrated, which most likely is related to the increased fatty acid utilization by the tissue [8]. In contrast, however, Veerkamp et al. [40] reported decreased L-FABP contents in the liver of streptozotocin-induced diabetic rats when compared to the control animals. Possibly, the duration of streptozotocin treatment (12 vs. 21 days) and differences in the assay procedure of FABP may have contributed to the discrepancy.

Peroxisome proliferation measured as an increase of FACO activity was relatively more pronounced in the heart than in liver (Fig. 1). This supports the marked increase in density of myocardial peroxisomes in experimental diabetes observed by others $[41,42]$. Although the myocardial peroxisomal $\beta$-oxidative activity might be relatively low, when compared to that of the liver [43], it has been demonstrated to be significant for the $\beta$-oxidation of very-long chain fatty acids $[44,45]$. Interestingly, no induction of the activities of cytochrome P450 subspecies (CYP1A1, CYP2E, and CYP4A1) could be demonstrated in this organ. Although, a number of other studies has provided evidence that very low levels of cytochrome P450, in particular CYP1A1, are present in the hearts of rabbit, [35], guinea pig [22] and rat [46], at present no other data are available on the occurrence of CYP4A1 activity in the heart. Since the microsomal P450 monooxygenase system is composed of a flavoprotein (NADPH$\mathrm{P} 450$ reductase) and multiple isoenzymes of the hemoprotein P450 [47, 48], the observed low activities might be due not only to a low content of cytochrome P450 but also to low activities of P450-reductase in heart. This notion is substantiated by the observation that reconstitution of cardiac microsomal fractions with purified NADPH-cytochrome P450 reductase dramatically increases cytochrome P4501A activity in vitro [22,49]. Therefore, it is possible that the low activity of cytochrome P450 monooxygenase in the heart, even after CYP1A1 induction, is based on a deficiency of NADPH-P450 reductase activity. The present study suggests that in cardiac cells the cytochrome P450 system at best may play a minor role in the formation of hydroxy fatty acids. It should be noted that we were not able to detect in rat heart, in contrast to liver and kidney, alcohol dehydrogenase activity (unpublished results). Thus, in cardionnyocytes the conversion of hydroxy fatty acids into the aldehyde and subsequently into the dicarboxylic form is unlikely.

The induction of CYP4A1 activity in kidney supports the observation that in this organ arachidonic acid can be converted not only into 20-HETE but also into $20-\mathrm{COOH}-$ arachidonic acid [50]. It should be noticed that the cytochrome
P450 system is capable of producing a variety of arachidonic acid metabolites which play an important role in electrolyte homeostasis and in the regulation of renal blood flow [50]. However, in contrast to heart and liver, no increase of FACO activity could be observed in kidney of streptozotocin-treated animals. In this respect, our data support the findings of Asayama et al. [41] that streptozotocin does not induce peroxisome proliferation in rat kidney. Also in mice feeding of high-fat diets failed to increase the number of peroxisomes and peroxisomal $\beta$-oxidation in kidney $[51,52]$.

The presence of both H- and L-FABP in kidney has been reported by various authors $[8,34]$, but the amounts are relatively low when compared to those observed in heart and liver, respectively. The small but significantly decreased L-FABP content of the diabetic kidney is difficult to explain, partly since the distinct functions of the two FABP types in kidney are not yet understood [8].

Our observations suggest that in kidney the role of the cytochrome P450 system is of greater importance for the conversion of fatty acids into bioactive substances regulating integrated renal function, such as participation in electrolyte homeostasis and regulation of tissue blood flow, than for the process of peroxisome proliferation which could help reducing fatty acid overload as associated with diabetes mellitus [50]. The role of FABP in the induction of these cytochrome P450-related activities has to be established.

The findings of the present study show that in the liver of diabetic rats a coordinated induction of CYP4A1, cytoplasmic FABP content and peroxisome proliferation occurs, similar to that observed in rats after administration with peroxisome proliferators (such as clofibrate) or feeding of high-fat diets. In heart, increased peroxisome proliferation and FABP content was not accompanied by an induction of any . Therefore, a role for cytochrome P4504A1 -mediated metabolites of fatty acids, such as dicarboxylic acids, in the induction of peroxisome proliferation and expression of FABP in the heart is unlikely. Finally, in kidney induction of cytochrome P450 activity was observed in absence of an increase in peroxisomal activity and in the content of FABP.

\section{Acknowledgement}

This study was supported by an Established Investigatorship of the Netherlands Heart Foundation to J.F.C.G. and a fellowship of the Royal Academy of Arts and Sciences to M. v. B.

\section{References}

1. DeFronzo RA: Pathogenesis of type 2 (non-insulin dependent) diabetes mellitus: A balanced overview. Diabetologica 35: 389-397, 1992 
2. Mannaerts GP, van Veldhoven PP: Role of peroxisomes in mammalian metabolism. Cell Biochem Funct 10: 141-151, 1992

3. Lock EA, Mitchell AM, Elcombe CR: Biochemical mechanisms of induction of hepatic peroxisome proliferation. Annu Rev Pharmacol Toxicol 29: 145-163, 1989

4. Vamecq J, Draye JP: Peroxisomal and mitochondrial beta-oxidation of monocarboxyl-CoA, omega-hydroxymonocarboxyl-CoA and dicarboxyl-CoA esters in tissues from untreated and clofibrate-treated rats. J Biochem 106: 216-222, 1989

5. Osmundsen H, Bremer J, Pedersen J1. Metabolic aspects of peroxisomal $\beta$-oxidation. Biochim Biophys Acta 1085: 141-158, 1991

6. Reddy JK, Mannaerts GP: Peroxisomal lipid metabolism. Annu Rev Nutr 14: 343-370, 1994

7. Issemann I, Prince R, Tugwood J, Green S: A role for fatty acids and liver fatty acid binding protein in peroxisome proliferation? Biochem Soc Trans 20: 824-827, 1992

8. Glatz JFC, van der Vusse GJ: Cellular fatty acid-binding proteins: their function and physiological significance. Progr Lipid Res 35: 243282, 1996

9. Kaikaus RM, Sui Z, Lysenko N, et al.: Regulation of pathways of extramitochondrial fatty acid oxidation and liver fatty acid-binding protein by long-chain monocarboxylic fatty acids in hepatocytes. Effect of inhibition of carnitine palmitoyltransferase 1. J Biol Chem 268: 26866-26871, 1993

10. Mortensen PB: Formation and degradation of dicarboxylic acids in relation to alterations in fatty acid oxidation in rats. Biochim Biophys Acta 1124: 71-79, 1992

11. Isseman I, Green S: Activation of a member of the steroid hormone receptor superfamily by peroxisome proliferators. Nature 347: 645650,1990

12. Beck F, Plummer S, Senior PV, Byrne S, Green S, Brammar W: The ontogeny of peroxisome-proliferator-activated receptor gene expression in the mouse and rat. Proc R Soc Lond B 247: 83-87, 1992

13. Mangelsdorf DJ, Thummel $\mathrm{C}$, Beato $\mathrm{M}$, et al.: The nuclear receptor superfamily: The second decade. Cell 83: 835-839, 1995

14. Osmundsen $\mathrm{H}$, Brodal B, Hovik R: A luminometric assay for peroxisomal $\beta$-oxidation. Effects of fasting and streptozotocin-diabetes on $\beta$-oxidation. Biochern J 260: 215-220, 1989

15. Kozuka H, Watanabe T, Horie S, Yamada J, Suga T, Ikeda T: Characteristics of peroxisome proliferation: Co-induction of peroxisomal fatty acid oxidation-related enzymes with microsomal laurate hydroxyiase. Chem Pharm Bull Tokyo 39: 1267-1271, 1991

16. Xu L, Ash M, Abdelaleern S, Lowe JE, Badr M: Hyperinsulinemia inhibits hepatic peroxisomal beta-oxidation in rats. Horm Metab Res 27: 76-78, 1995

17. Gustafsson J-Å, Gearing K, Widmark E, et al.: Effects of fatty acids on gene expression mediated by a member of the nuclear receptor supergene family. Prog Clin Biol Res 387: 21-28, 1994

18. Kaikaus RM, Chan WK, Lysenko N, Ray R, Ortiz de Montellano PR, Bass NM: Induction of peroxisomal fatty acid beta-oxidation and liver fatty acid-binding protein by peroxisome proliferators - mediation via the cytochrome P-45OlVA1 omega-Hydroxylase pathway. J Biol Chem 268: 9593-9603, 1993

19. Kaikaus RM, Chan WK, Ortiz de Montellano PR, Bass NM: Mechanisms of regulation of liver fatty acid-binding protein. Mol Cell iochem 123: 93-100, 1993

20. Shimojo N, Ishizaki T, Imaoka S, Funae Y, Fujii S, Okuda K: Changes in amounts of cytochrome-P450 isozymes and levels of catalytic activities in hepatic and renal microsomes of rats with streptozocininduced diabetes. Biochem Pharmacol 46: 621-627, 1993

21. Glatz JFC, van Breda E, Keizer HA, et al.: Rat heart fatty acid-binding protein content is increased in experimental diabetes. Biochem Biophys Res Commun 199: 639-646, 1994
22. McCallum GIP, Horton JE, Faikner KC, Bend JR: Microsomal Cytochrome-P450 1A1 dependent monooxygenase activity in guinea pig heart - induction, inhibition, and increased activity by addition of exogenous NADPH Cytochrome-P450 reductase. Can J Physiol Pharmacol 71: 151-156, 1993

23. Rutten AAJJL, Falke HE, Catsburg JF, et al.: Interlaboratory comparison of total cytochrome $\mathrm{P}-450$ and protein determination in rat liver microsomes. Reinvestigation of assay conditions. Arch Toxicol 61: 27-33, 1987

24. Vannecq J: Fluorometric assay of peroxisomal oxidases. Anal Biochem 186: 340-349, 1990

25. Mannaerts GP, van Veldhoven P, van Broekhoven A, Vandebroek G, Debeer LJ: Evidence that peroxisomal acyl-CoA synthetase is located at the cytoplasmic side of the peroxisomal membrane. Biochem J 204: 17-23, 1982

26. Vork MM, Glatz JFC, Surtel DA, Knubben HJ, van der Vusse GJ: A sandwich enzyme linked immuno-sorbent assay for the determination of rat heart fatty acid-binding protein using the streptavidin-biotin system. Application to tissue and effluent samples from normoxic rat heart perfusion. Biochim Biophys Acta 1075: 199-205, 1991

27. Van Nieuwenhoven FA, Verstijnen CPHJ, van Eys GJJM, et al.: Fatty acid transfer across the myocardial capillary wall: No evidence of a substantial role for cytoplasmic fatty acid binding protein. J Mol Cell Cardiol 26: 1635-1647, 1994

28. Onnura T, Sato R. The carbon monoxide-binding pigment of liver microsomes. II. Solubilization, purification, and properties. J Biol Chem 239: 2379-2385, 1964

29. Stegeman JJ, Woodin BR, Klotz AV, Wolke RE, Orme-Johnson NR: Cytochrome P-450 and monooxygenase activity in cardiac microsomes from fish Stenotomus chrysops. Mol Pharmacol 21: 517-526, 1982

30. Engels W, Kamps MA, Lemmens PJ, van der Vusse GJ, Reneman RS: Determination of prostaglandins and thromboxane in whole blood by high-performance liquid chromatography with fluorimetric detection. J Chromatogr 427: 209-218, 1988

31. Reinke LA, Moyer MJ: p-Nitrophenol hydroxylation: A microsomal oxidation which is highly induceble by ethanol. Drug Metab Dispos 13: 548-552, 1985

32. Wallenstein S, Zucker C, Fleiss JL: Some statistical methods useful in circulation research. Circ Res 47: 1-9, 1980

33. Seyer-Hansen K. Renal hyperthrophy in experimental diabetes. Kidney Int 23: 643-646, 1983

34. Maatman RG, van de Westerlo EM, van Kuppevelt TH, Veerkamp JH: Molecular identification of the liver- and the heart-type fatty acid-binding proteins in human and rat kidney. Use of the reverse transcriptase polymerase chain reaction. Biochem J 288: 285-290, 1992

35. Abraham NG, Pinto A, Levere RD, Mullane K: Identification of heme oxygenase and cytochrome P-450 in the rabbit heart. J Mol Cell Cardiol 19: 73-81, 1987

36. Gottlicher M, Widmark E, Li Q, Gustafsson JA: Fatty acids activate a chimera of the clofibric acid-activated receptor and the glucocorticoid receptor. Proc Nati Acad Sci USA 89: 4653-4657, 1992

37. Göttlicher M, DemozA, Svensson D, Tollet P, Berge RK, Gustafsson JA: Structural and metabolic requirements for activators of the peroxisome Proliferator-Activated receptor. Biochem Pharmacol 46: 2177-2184, 1993

38. Barnett CR, Flatt PR, Ioannides C: Modulation of the rat hepatic cytochrome $\mathrm{p} 450$ composition by long-term streptozotocin-induced insulin-dependent diabetes. J Biochem Toxicol 9: 63-69, 1994

39. Shimojo N: Cytochrome P450 changes in rats with streptozocininduced diabetes. Int J Biochern 26: 1261-1268, 1994

40. Veerkamp JH, van Moerkerk HTB, van den Born J: No correlation between changes in fatty-acid binding content and fatty acid oxidation capacity of rat tissues in experimental diabetes. Int J Biochem Cell Biol 28: 473-478, 1996 
41. Asayama K, Yokota S, Kato K. Peroxisomal oxidases in various tissues of diabetic rats. Diabetes Res Clin Pract 11: 89-94, 1991

42. Yokota S, Asayama K: Proliferation of myocardial peroxisomes in experimental rat diabetes: A biochemical and immunocytochemical study. Virchows Arch B 63: 43-69, 1992

43. Chu C, Mao L-F, Schultz H: Estimation of peroxisomal $\beta$-oxidation in rat heart by a direct assay of acyl-CoA oxidase. Biochem J 302: 23-29, 1994

44. Norseth J, Thomassen MS. Stimulation of microperoxisomal ISoxidation in rat heart by high-fat diets. Biochim Biophys Acta 751: 312-320, 1983

45. van der Vusse GJ, Glatz JFC, Stam HCG, Reneman RS: Fatty acid homeostasis in the normoxic and ischemic heart. Physiol Rev 72: 881940, 1992

46. Guengerich FP, Mason PS: Immunological comparison of hepatic and extrahepatic cytochromes P-450. Mol Pharmacol 15: 154-164, 1979

47. Nelson DR, Kamataki T, Waxman DJ, et al.: The P450 superfamily: Update on new sequences, gene mapping, accession numbers, early trivial names of enzymes, and nomenclature. DNA Cell Biol 12: 151,1993

48. Porter TD, Coon MJ: Cytochrome P-450. Multiplicity of isoforms, substrates, and catalytic and regulatory mechanisms. J Biol Chem 266: 13469-13472, 1991

49. Wu S, Moomaw CR, Tomer KB, Faick JR, Zeldin DC: Molecular cloning and expression of CYP2J2, a human cytochrome P450 arachidonic acid epoxygenase highly expressed in heart. J Biol Chem 271: 3460-3468, 1996

50. McGiff JC, Quilley CP, Carroll MA: The contribution of cytochrome P450-dependent arachidonate metabolites to integrated renal function. Steroids 58: 573-579, 1993

51. Decraemer D, Vamecq J, Roels F, Vallee IL, Pauwels M, Vandenbranden C: Peroxisomes in liver, heart, and kidney of mice fed a commercial fish oil preparation: Original data and review on peroxisomal changes induced by high-fat diets. J Lipid Res 35: 1241-1250, 1994

52. Asayama K, Okada Y, Kato K: Peroxisomal beta-oxidation in liver and muscles of gold-thioglucose-induced obese mice: Correlation with body weight. Int J Obes 15: 45-49, 1991 
